\title{
The use of deep friction massage with olive oil as a means of prevention and treatment of sports injuries in ancient times
}

\author{
Nikitas N. Nomikos¹, George N. Nomikos², Demetrios S. Kores²
}

${ }^{1}$ Faculty of Physical Education and Sports Science - Medical School, Athens, Greece ${ }_{21} 1^{\text {st }}$ Department of Orthopaedics, Athens University Medical School, Athens, Greece

Submitted: 31 December 2009

Accepted: 9 March 2010

Arch Med Sci 2010; 6, 5: 642-645

DOI: 10.5114/aoms.2010.17074

Copyright @ 2010 Termedia \& Banach

\begin{abstract}
The aim of this research was to analyse the use of olive oil as a means of prevention and treatment of sports injuries in the ancient world. The method adopted was based on a thorough study of Greek and world literature. Writings of major ancient philosophers and physicians such as Hippocrates, Aristotle, Philostratus, and Lucian have been analysed in depth. According to the results, the use of massage, together with olive oil rub, helped to reduce muscle fatigue, to remove lactic acid, and to prevent the occurrence of sports injuries through flexibility provided to the skin of athletes. The therapeutic use of oil in the ancient world was fully recognized; and as a result Athenian athlothetes (sponsors of sporting events) provided free oil to all sport facilities where athletes could make free use of it [1].
\end{abstract}

Key words: trauma, sport injuries, therapy, olive oil, deep friction massage.

\section{Introduction}

The ancient Greeks had early recognized the advantages of deep friction massage of the body with olive oil. In the eighth century BC athletes, especially those active in wrestling and pangration, rubbed their bodies with oil or threw sand-dust (кóviv) on them [2]. In the initial stage of the massage, a dry rub was performed gently with the palm, a touch on the naked body of the exercisers that prepared the athletes physically and psychologically just before they entered the playing field [3]. The rub, "massage" (Greek word from the ancient verb "masso = give assistance operations") [4, 5], was of light intensity and progressively it became stronger [6]. The ancients aimed in this way to achieve a gradual increase in the rate of metabolic processes, so the athlete's body could respond in the best way to the required activity.

The main objective of this article is to analyse and to substantiate the beneficial effects of using deep friction massage with olive oil as a means of prevention and treatment of sports injuries.

\section{Search strategy}

We pursued this objective by reviewing (study design) the ancient literature in relation to modern literature. In this way we wish to attribute 
to this study a beneficial role and usage, so that the modern community can adopt its use as the ancients did. For this purpose we visited the National Library of Greece, the Gennadius Library / The Library of the American School of Classical Studies at Athens, the Library of the University of Athens / Medical School and other institutions. The search strategy we followed was an extensive review of the Greek and world literature. Writings of significant physicians such as Hippocrates and Galen were analysed.

\section{Obtained results}

The whole process was performed in a specific part within sports institutions (Palaestra and Gymnasium), called aleiptirion [7]. According to Aristophanes, the massage was performed by the umbilicus [8]. An individual with special knowledge on human anatomy carried out the process of massage with oils. He was called the aleiptes [9], the paidotrivis, or the "trainer" or other co-athlete [3]. The actions of the rub were mostly mild and gentle in such a manner as to avoid sudden movements that might cause injury to the soft tissue (muscle) of the trainee [10]. A knowledge of the human anatomy was significant for beneficial and not harmful massage. Not everyone could do massage. As a prerequisite knowledge of the human body and its mechanisms was necessary at a theoretical and practical level, so that aleiptes could not only promote the mental health of the person who accepted his services, but also be able to actively assist in the treatment of any injuries [11]. Characteristic of the therapeutic usefulness of the rub with olive oil is the reference in Patrologia Minge of how the aleiptes could reset the bone to articulate "the dislocated limb through the art of massage and settle it back into place" [12].

Rubbing with oil was considered so important in the ancient world that Philostratus in his book "Gymnastics-Epistolai" considered it necessary to provide instructions on how to conduct effective rubbing with olive oil [13]. In particular, the great writer of antiquity says: "The trainer should apply rubbings for the athletes of light and heavy events, with a moderate amount of oil, especially the lower parts, and wipe them well" [13]. The same author, in his effort to stress the positive effects of rubbing the body with oil, states: "they rubbed themselves with the oil of the wild olive. This style of living made them free from sickness and they kept their youth a long time. Some of them competed in eight Olympic Games, some others in nine; they were also excellent soldiers." [14]. Moreover, Philostratus believed that exercise combined with proper nutrition and rubbing acted positively even in the prevention of diseases [15].

Furthermore, Hippocrates, the father of medicine, in his work "About Diet" refers to differences between exercises in oil and those in dust: "LXV. Exercises in dust differ from those in oil, in that dust is cold and oil is warm. In winter oil promotes more growth, because it prevents the cold from being carried from the body. In summer, oil, producing excess of heat, melts the flesh, when the latter is heated by the season, by the oil and by the exercise. In summer exercise in dust promotes growth more, for by cooling the body it prevents its being heated to excess. But in winter dust is chilling, or even freezing. To remain in the dust after exercise in summer benefits by its cooling properties, if it be for a short time; if it be for long, it dries the body to excess and renders it hard as wood. Rubbing with oil and water softens the body, and prevents it becoming over-heated" [16].

According to these reports, the reasons that the athletes rubbed their bodies with oil varied and this constitutes a subject of analysis for various interpretations/theories. Some authors believe that rubbing with oil helped to raise the temperature of the body (warm it up) and further lead to flexibility (limberness) of the muscles before exercise. Some others think that the oil protected the body from the sun and other elements of nature [17]; it is theorized that oil had heat-insulating characteristics. According to another theory the oil produced a glistening body which was aesthetically pleasing and desirable, or that the coating of oil prevented the loss of body fluids during exercise (protection from dehydration) [17]. Pliny believed that oil protected the body against the cold [17]. Massage with oil was so important that the nomenclature of two sport professions, paidotrivis (boy rubber) and aleiptes (oiler), came from it [18]. For wrestlers and pankratiasts the olive oil had the added function of reducing skin abrasion and hindering dirt from becoming packed into the pores of athletes' skin [18].

Ailianos claimed that rubbing with oil was first

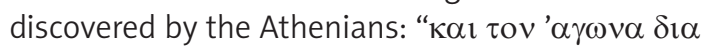
$\tau \omega \nu \sigma \omega \mu \alpha \tau \omega \nu$ $\eta \lambda \varepsilon \iota \psi \alpha \nu \tau 0^{\prime}$ " [19]. The person (aleiptes) who was charged with the performance of the necessary manoeuvres of oil massage had to be aware of the strength and age of the trainee $[20,21]$. The implementation of deep friction massage with oil was important not merely for warming up, but also to achieve the desired performance. After the end of the sporting event the athlete scraped his body with a strigil (stlengis), a curved tool. The strigils removed from the body surface area not merely the products of the metabolic processes (sweat), but also the combination of oil, sweat and dust. This mixture was called gloios and it was collected in vases and sold for its presumed medical value [17]. In addition athletes also used a sponge in order to wash themselves down after the scraping was completed. 
When the procedure of scraping ended, aleiptes of palaestra applied to athletes a massage in order to appease the fatigued body [3, 22]. According to Lucian the olive oil had positive effects on athletes' bodies: "Then we rub their bodies with olive oil and work it in so that they will have better tone." [23].

Furthermore, according to Hippocrates the postexercise massage helped to alleviate muscle pain [6]. From the above reference, it can be theorised that Hippocrates and his contemporaries were aware of the analgesic properties of deep friction. The correctness of this theory is verified by modern research findings according to which massage increases local blood flow, relaxes muscles and further mobilizes and breaks down the scar tissue [24]. In particular, the local friction succeeds in increasing the local temperature and contributes to better blood flow, due to induced vasodilation and increased permeability of blood vessels.

However, in ancient Greece deep friction massage (DFM) in conjunction with olive oil was used not only for therapeutic purposes, since oil, apart from treatment and analgesic properties, had another use, as a preventive measure for averting sports injuries. Oil not only allowed freedom of movement, but also helped to prevent injuries. The skin and thus the body by the friction with oil becomes flexible. The oil causes the forces to be less intense and longer compared to non-oiled skin. The oil greatly facilitated the escape of an athlete from painful and injury-prone holds, such as trapping the neck (trachilismos). Especially in wrestling an oiled body offered the opportunity for the athlete to avoid dangerous holds applied by an opponent, such as entrapment of the waist

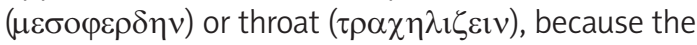
body was slippery and thus the implementation of the holds was difficult [25]. The applied oil, through increased slipperiness, helped the body to reduce the intensity and duration of hazardous holds. In combination with the increased capacity of the skin (through flexibility) to receive larger forces, the oil makes the generation of sports injuries more difficult.

Apart from the aforementioned use, oil was likely to have additional benefits in terms of prevention. In particular, the oil when it was rubbed on the body did not allow or prevented the full exposure of the body to the negative effects of solar ultraviolet radiation. However, this has not yet been established scientifically (the protection offered by olive oil from the sun) and the confirmation may be an area for new research efforts and applications in modern public health.

\section{Discussion}

Oil and its beneficial effects were well known to the ancient world. The Greeks through the use of olive oil succeed in increasing skin elasticity and blood supply to the underlying muscle. Also postexercise massage combined with the oil rub resulted in faster recovery of the athlete, as the blood flow increased and the product of metabolic processes (lactic acid) was removed rapidly from the extended blood vessels. Furthermore, the oil rub gave flexibility and lubricity to the body of athletes. This resulted in its use being adopted not only as a means of treatment, but also for the prevention of sports injuries.

Post-exercise deep friction massage combined with the application of oil was beneficial in reducing muscle fatigue. In particular, the friction increased the blood flow of the underlying tissue (at the local level) and helped to achieve faster removal of lactic acid from the tissues of the fatigued neuromuscular system of the athlete. In this way ancient Greeks achieved better recovery of the acid-base balance of the body and further restored the $\mathrm{pH}$ of the arterial blood to normal levels ( $\mathrm{pH} 7.35-7.45)$. The ancients knew through visual observation the beneficial results of using oil as a means of reducing muscle fatigue and faster recovery of the athletes.

The beneficial properties of deep friction massage (DFM) have been confirmed by recent studies. According to a synchronous study, massage has both reflective and mechanical action [26]. It contributes to effective reduction of increased muscle tone and further increases venous return [26]. In addition it reduces levels of creatine kinase and the number of circulating neutrophils, and delays the onset of muscle pain after eccentric exercise, through disruption of the inflammatory response [24].

Steward et al. state that DFM has a therapeutic modality for tendinitis, muscle strains, ligamentous sprains, and capsulitis of the trapezio-firstmetacarpal joint [27]. Depending on the stage and site of the lesion, treatment sessions may be as brief as $5 \mathrm{~min}$ or as long as $20 \mathrm{~min}$. Many therapists find DFM to be very effective but they state that treatment is too fatiguing to administer [27]. Brosseau et al. state that deep transverse friction massage (DTFM) is one of several physiotherapy interventions suggested for the management of tendinitis pain [28]. Mayer et al. reported that pain (in 31 male runners with unilateral, untreated Achilles tendinopathy, who completed 4 weeks of either physiotherapy, 10 treatments: deep friction, pulsed ultrasound, ice, sensory motor training) was reduced to $<50 \%$ of the baseline [29]. According to Boisaubert et al., for the long term, physiotherapy (pulsed ultrasound, deep friction massage and exercise programme) is the best option that could be applied [30].

Patricia Benjamin supports Marys McMillan's thesis that the use of cod liver oil or olive oil is 
advocated for its nutritive value when massaging young children [31]. Dana Michelsen states that back rubs have benefits [30]. Also exercise, even of the passive type, is essential in illness. The same author writes that massage with a warmed lubricant (such as olive oil) is encouraged in order to prevent depressed circulation and tissue breakdown, and to aid natural skin tone [32]. According to Ostermann et al., repeated rhythmic embrocation with oil may improve mood, pain perception, and the ability to cope with pain in patients with chronic low back pain [33]. These recent findings are in accordance with the beneficial effects already observed in ancient Greece and confirm the positive effects of deep friction massage with olive oil to treat injuries.

From this study, we can conclude that DFM in combination with olive oil has beneficial effects as a means of prevention and treatment of sports injuries. According to the results and the discussion section of this article, DFM and olive oil helped the athletes to increase the local temperature of the rubbed muscle and contributed to better blood flow. Furthermore, the body through friction with oil becomes more flexible and thus the generation of injuries during sports is more difficult. In addition, post-exercise massage combined with oil rub resulted in faster recovery of the athlete. The friction increased the blood flow of the underlying tissue and in that way contributed to faster removal of lactic acid and, as a result, the rapid recovery of the athlete.

The beneficial results of deep friction massage with oil as derived from ancient Greek literature and as outlined in this research is a fact; but it needs further scientific research by scientists of moderate sports history and especially sports medicine, in order to find application to the current needs of athletes. It is anticipated that this article will be a stimulus so that further trials, using appropriate methods and adequate sample sizes, will be conducted so as to reveal the benefits of olive oil application and the potential applications in modern medicine and coaching.

\section{References}

1. Aristotle. The Athenian Constitution LX, 3.

2. Pausanias. I. 44, 1.

3. Giannakis T. History of Physical Education. Athens: Andrikos Publishing Company; 1998, 66.

4. Aristophanes. Peace. 44.

5. Aristophanes. The Knights. 55.

6. Giannakis T. History of physical education. Athens: Andrikos Publishing Company; 1998, 67.

7. Liddell HG, Scott R. Dictionary of the Greek Language. Athens: J Sideris; 1977, 103.

8. Aristophanes. Clouds. 977.

9. Aristotle. Nicomachean Ethics. 2, 6, 7.

10. Lucian. Anaharsis or About Exercises. 1.
11. Nomikos N. Sport Injuries during the Athletic Games in Antiquity. University of Athens; 2009, 113.

12. Patrologia. MIGNE 49, 972.

13. Vasilios M. Philostratos, Concerning Gymnastics 50. Athens: Cactos Publishing Company; 1992, 94-5.

14. Vasilios M. Philostratos, Concerning Gymnastics 50. Athens: Cactos Publishing Company; 1992, 84-5.

15. Vasilios M. Philostratos, Concerning Gymnastics 50. Athens: Cactos Publishing Company; 1992, 48-9.

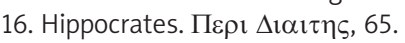

17. Miller SG. Ancient Greek Athletics. Yale University Press, 2004, 15.

18. Poliakoff MB. Combat sports in Ancient World. Yale University Press, 1987, 14.

19. Ailianos. Diversity history, 38.

20. Oribasius VI. 13.

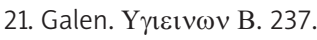

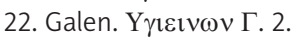

23. Lucian, Anaharsis, 24.

24. Gold DA, Saunders M, Huie G. Rehabilitation and therapeutic techniques. In: Scuderi GR, McCann PD, Bruno PJ, Kibiuk LV, editors. Sports Medicine. Principles of Primary Care. USA-Greece: Mosby, Paschalidis; 1997, 746.

25. John of Damascus or John Damascene, P.G. 96, 181.

26. Gotlin RS, Palmer MA. The Spinal Column. In: Scuderi GR, McCann PD, Bruno PJ, Kibiuk LV, editors. Sports Medicine. Principles of Primary Care. USA-Greece: Mosby, Paschalidis, 1997, 865.

27. Steward B, Woodman R, Hurlburt D. Fabricating a splint for deep friction massage. J Orthop Sports Phys Ther 1995; 21:172-5.

28. Brosseau L, Casimiro L, Milne S, et al. Deep transverse friction massage for treating tendinitis. Cochrane Database Syst Rev 2002; 4: CD003528.

29. Mayer F, Hirschmüller A, Müller A, Schuberth M, Baur H. Effects of short-term treatment strategies over 4 weeks in Achilles tendinopathy. Br J Sports Med 2007; 41: e6.

30. Boisaubert B, Brousse C, Zaoui A, Montigny JP. Nonsurgical treatment of tennis elbow. Ann Readapt Med Phys 2004; 47: 346-55.

31. Benjamin PJ. Rub it on, rub it in: a brief history of oils and liniments used in massage. A closer look at the substances used years ago with massage attests to their variety, and to the great care that went into choosing them. Massage Therapy Journal 2003; 140.

32. Michelsen D. Giving a Great Back Rub. Am J Nurs 1978; 78: 1197-200.

33. Ostermann T, Blaser G, Bertram M, Michalsen A, Matthiessen PF, Kraft K. Effects of rhythmic embrocation therapy with solum oil in chronic pain patients: a prospective observational study. Clin J Pain 2008; 24: 237-43. 